\title{
Identification and Prediction of Potential Drug-like Compounds From Ruku-Ruku Leaves (Ocimum tenuiflorum Linnen) in West Sumatera
}

\author{
Hesty Parbuntari ${ }^{1 *}$ Sri Benti Etika ${ }^{1}$ M. Mulia ${ }^{1}$
}

\author{
${ }^{1}$ Dept. of Chemistry, Faculty of Mathematics and Science (FMIPA), Universitas Negeri Padang, Padang, Indonesia \\ *Corresponding author. Email: hesty5193@fmipa.unp.ac.id
}

\begin{abstract}
Ruku-ruku leaves are one of the natural resources in West Sumatra. However, the use of ruku-ruku leaves nowadays has only been used to enrich the taste of cuisine such as fish curry dishes. The distinctive odor of the ruku-ruku leaves can eliminate the fishy odor in the fish. This distinctive odor comes from secondary metabolite compounds on the leaves of the ruku-ruku. Based on previous research, the content of secondary metabolites can be differentiated from one region to another. In fact, to maximise its function, secondary metabolites are first identified and tested for biological activity. Therefore, this study identified secondary metabolites in the ruku-ruku leaves. The results showed that there were about 17 secondary metabolite compounds present in the ruku-ruku leaves. Limonnen, geranyl acetate, and citronellal are the three compounds that have the highest percentage in ruku-ruku leaves, respectively, $59.04 \%, 14.80 \%$, and $7.81 \%$. In addition, secondary metabolites present in the ruku-ruku leaves have biological activities such as antibacterial properties.
\end{abstract}

Keywords: ruku-ruku leaves, secondary metabolite, antibacterial.

\section{INTRODUCTION}

Minang cuisine is well-known for its flavour because of the various spices that are included in the cuisine. People in West Sumatra have a various way to enrich their cuisine taste. For example, curry dishes such as fish curry which usually becomes fishy if the processing is not right then the people in West Sumatra process these fish dishes using ruku-ruku leaves to remove the fishy taste. The distinctive taste of ruku-ruku leaves can reduce the fishy taste from fish.

The distinctive taste on the ruku-ruku leaves is similar to the smell on the basil leaves. This basil has essential oils which are secondary metabolites. The content of essential oils from basil leaves is a group of terpenoid compounds (monoterpenes and sesquiterpenes). Based on the previous research, basil essential oil which is distilled using Clevenger-hydrodistillation contains geranial (24.74\%), neral $(28.11 \%)$, curcumen $(14.28 \%)$ and other components $(32.87 \%)$. While essential oils distilled using microwave asissted hydrodistillation contain geranial compounds $(41.85 \%)$, neral $(29.07 \%)$, curcumen $(0.76 \%)$ and other components $(28.32 \%)$. Geranial and Z-citral (neral) are the constituent components of citral which is an aldehyde group. So, the most composition of basil essential oil is a citral compound [1]

The content of essential oils between one type of compound can be differentiated from one another. Initial phytochemical tests in several areas in West Sumatra such as Payakumbuh, Batusangkar, Lubung Alung, Padang Panjang, and Pesisir Selatan showed some differences in the results of identification of flavonoids, steroids, or terpenoids. This is caused by several factors such as ambient temperature, humidity, light exposure and salinity [2]

Secondary metabolites are bioactive compounds that are able to function as antibacterial, antioxidant, and anticancer. The number of chemical components that exist in a plant such as Ocimum basilium L. and various biological activities related to one another [3]. Thus, identification needs to be held to maximise the benefits of ruku-ruku leaves as a source of bioactive compounds.

\section{MATERIALS AND METHODS}

\subsection{Tools and Materials}

This research used some tools such as test tubes, mortar, pippete, volumetric flask, measuring cylinder, beaker glass, spatula, spraying bottle, filter paper, funnel, and distillation set. The materials were ruku-ruku leaves (Ocimum tenuiflorum Linnen) from Batusangkar, nhexane as solvent in extraction, deionised water for steam distillation, sodium sulfate anhydrous for removing water, concentrated sulfuric acid, magnesium powder, cottons, acetic anhydride, concentrated hydrochloric acid, ethanol 
$70 \%$, aquadest, Wagner reagent, Dragendorff reagent, and Mayer reagent.

\subsection{Methods}

Distillation and Extraction of Ruku-Ruku Leaves

Ruku-ruku leaves were collected from Batusangkar, West Sumatera. Small and dried pieces of ruku-ruku was prepared and kept in the flask as the raw material for steam distillation. Then, $50 \mathrm{~mL}$ of deionized water was added into $15 \mathrm{~g}$ of dried ruku-ruku. The distillation was performed at $100 \mathrm{oC}$ for $4-5$ hours. The distillate is extracted with n-hexane three times and added sodium anhydrous to remove the remaining water. Essential oils are stored in a dark glass vial at $4 \mathrm{oC}$ for further analysis.

Characterisation of the Extract of Ruku-Ruku Leaves Identification of the volatile compounds from the leaves was performed using an Agilent 5973 GC hyphenated mass spectrometer (MS) system fitted with a DB5 MS (5\%-phenyl)-methylpolysiloxane fused silica column with dimensions $30 \mathrm{~m} \times 250 \mu \mathrm{m}$, i.e., film thickness $0.25 \mu \mathrm{m}$, (Agilent Technologies, Mulgrave, VIC, Australia). Helium (99.99\% purity) was used as the carrier gas at a flow rate of $1.5 \mathrm{ml} / \mathrm{min}$. The split ratio was 50:1. The initial GC oven temperature was $40{ }^{\circ} \mathrm{C}$ for $3 \mathrm{~min}$, after which it was raised from 40 to $250^{\circ} \mathrm{C}$ at $6{ }^{\circ} \mathrm{C} / \mathrm{min}$, where it was held for $5 \mathrm{~min}$. The injection port, transfer line, and source temperatures were 250,280 , and $230{ }^{\circ} \mathrm{C}$, respectively. The mass scan range was $41-415 \mathrm{~m} / \mathrm{z}$. Data acquisition and processing were performed using MSD ChemStation (E02.00.493) (Agilent Technologies, Mulgrave, VIC, Australia). Qualitative identification was performed using GC-MS reference libraries (Adams 2007, Wiley 7th edition, and NIST 2.0) using a $80 \%$ similarity match cut off value. Concentrations of the studied compounds were calculated from the peak areas in the total ion chromatograms. The relative abundance of each compound was obtained from electronic integration measurements using the mean of three replicates. Kovats standard retention indices were determined from the retention times of a series of n-alkane mixture analyzed under identical conditions.

\section{RESULT AND DISCUSSION}

Table 1. Composition of compounds contained in the rukuruku leaves.

\begin{tabular}{|c|c|c|c|}
\hline $\begin{array}{c}\text { No } \\
\cdot\end{array}$ & $\begin{array}{c}\text { Retention } \\
\text { time (min) }\end{array}$ & Compound & $\begin{array}{c}\text { Percentage } \\
(\%)\end{array}$ \\
\hline 1. & 1,223 & $\begin{array}{c}\text { Tricyclo[6,3,3,0] tetradec- } \\
\text { 4-ene,10,13-dioxo- (A) }\end{array}$ & 0.42 \\
\hline
\end{tabular}

\begin{tabular}{|c|c|c|c|}
\hline No & $\begin{array}{l}\text { Retention } \\
\text { time (min) }\end{array}$ & Compound & $\begin{array}{l}\text { Percentage } \\
(\%)\end{array}$ \\
\hline 2. & 1,411 & Trichloromethane (B) & 0.91 \\
\hline 3. & 3,323 & 1S- $\alpha$-pinene $(\mathbf{C})$ & 1.55 \\
\hline 4. & 4,063 & $\begin{array}{l}\text { 6-methylhept-5-en-2-one } \\
\text { (D) }\end{array}$ & 1.35 \\
\hline 5. & 4,157 & $\begin{array}{l}\text { Myrcene / 7-methyl-3- } \\
\text { methyl-1,6-octadiene (E) }\end{array}$ & 0.60 \\
\hline 6. & $\begin{array}{l}5,009 \\
5,184 \\
5,202 \\
5,273\end{array}$ & Limonene $(\mathbf{F})$ & 59.04 \\
\hline 7. & 5,410 & $\begin{array}{c}\beta \text {-ocimene/ 3,7-dimethyl- } \\
\text { 1,3,6-octatriene }(\mathbf{G})\end{array}$ & 3.72 \\
\hline 8. & 6,851 & $\begin{array}{l}\text { (2Z)-3,7-dimethyl-2,6- } \\
\text { octadien-1-ol (H) }\end{array}$ & 1.22 \\
\hline 9. & 8,692 & $\begin{array}{l}\text { Citronellal / 3,7-dimethyl- } \\
\text { 6-octenal (I) }\end{array}$ & 7.81 \\
\hline 10. & 11,791 & $\begin{array}{l}\text { Citronellol / 3,7-dimethyl- } \\
\text { 6-octen-1-ol (J) }\end{array}$ & 1.24 \\
\hline 11. & 13,006 & $\begin{array}{l}\text { (2E)-3,7-dimethyl-2,6- } \\
\text { octadien-1-ol }(\mathbf{K})\end{array}$ & 1.84 \\
\hline 12. & 17,994 & $\begin{array}{l}\text { 2,6-dimethyl-2,6- } \\
\text { octadiene }(\mathbf{L})\end{array}$ & 0.60 \\
\hline 13. & 19,280 & $\begin{array}{l}\text { methyl(2E)3-phenyl-2- } \\
\text { propenoate }(\mathbf{M})\end{array}$ & 0.60 \\
\hline 14. & 19,492 & $\begin{array}{c}\text { Geranyl acetate/ (2E)-3,7- } \\
\text { dimethyl;-2,6-octadienyl } \\
\text { acetate }(\mathbf{N})\end{array}$ & 14.80 \\
\hline 15. & 19,680 & $\begin{array}{c}\text { cis-Geraniol/3,7- } \\
\text { dimethyl-2,6-octadien-1- } \\
\text { ol }(\mathbf{O})\end{array}$ & 0.60 \\
\hline 16. & 23,735 & $\begin{array}{l}\text { Germacene/ 8-isopropyl- } \\
\text { 1-methyl-5-methylene- } \\
\text { 1,6-cyclodecadiene }(\mathbf{P})\end{array}$ & 0.60 \\
\hline 17. & 29,316 & $\begin{array}{c}\text { farnesyl acetate/ 3,7,11- } \\
\text { trimethyl-1,6,10- } \\
\text { Dodecatrien-3-ol }(\mathbf{Q})\end{array}$ & 3.10 \\
\hline
\end{tabular}




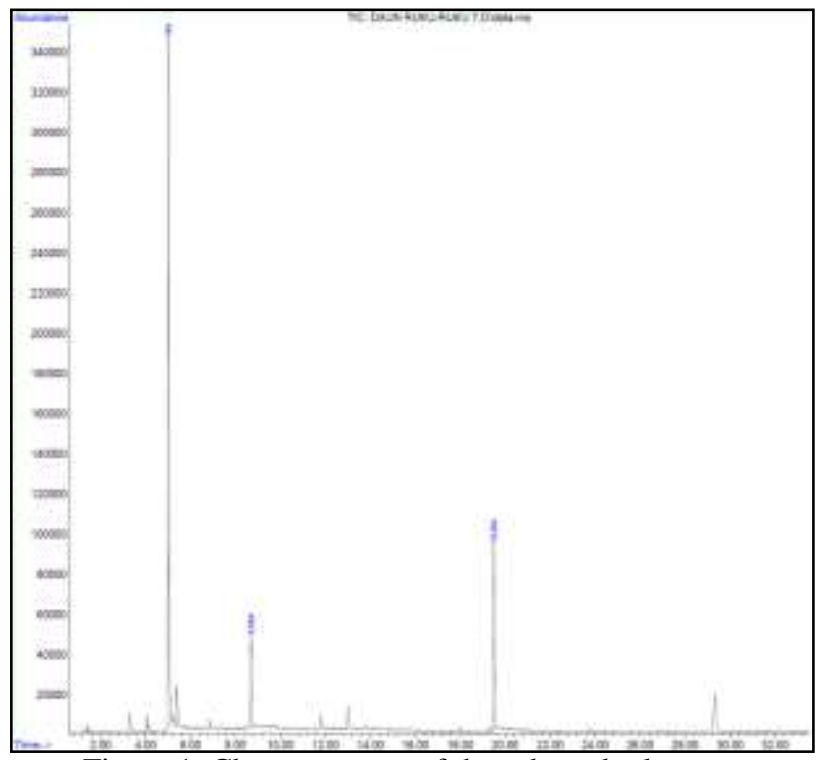

Figure 1. Chromatogram of the ruku-ruku leaves

Secondary metabolites contained in a plant can be differentiated from one another even though the plant is a plant with the same species. One of the factors that can influence is the condition of the plant's growing environment. The study explains that the leaves of rukuruku in several regions in West Sumatra show different phytochemical test results. Based on the research of the previous study [2], the results of alkaloid, steroid, terpenoid, and flavonoid tests showed quite different results between several regions.

Early identification such as phytochemical testing becomes important to be done to find out ruku-ruku leaves which come from areas that contain more varied secondary metabolites, so that the ruku-ruku can be maximised as a plant producing medicinal compounds. Based on the previous research, areas that produce ruku-ruku with the best secondary metabolite levels are areas that do not contain too high salinity levels, not too close to the coast, not too humid and get enough sun exposure. Therefore, this study uses a sample of ruku-ruku from the Batusangkar area that meets the criteria stated by previous research. Ruku-ruku leaves extract in n-hexane shows positive results on the presence of alkaloids, flavonoids, steroids or terpenoids, and sapponin [2].

Secondary metabolites are compounds that are included in the group of bioactive molecules. This means that these compounds can be developed or function as drug compounds that have certain activities such as antioxidants, anti-inflammatory, antidiabets, and even anticancer. Table 2 shows the compounds contained in Ruku-Ruku leaves based on GCMS analysis. Most of these compounds are compounds that have medical activity. This identification analysis with GC MS is guided by matching the results of the analysis with molecular data banks.
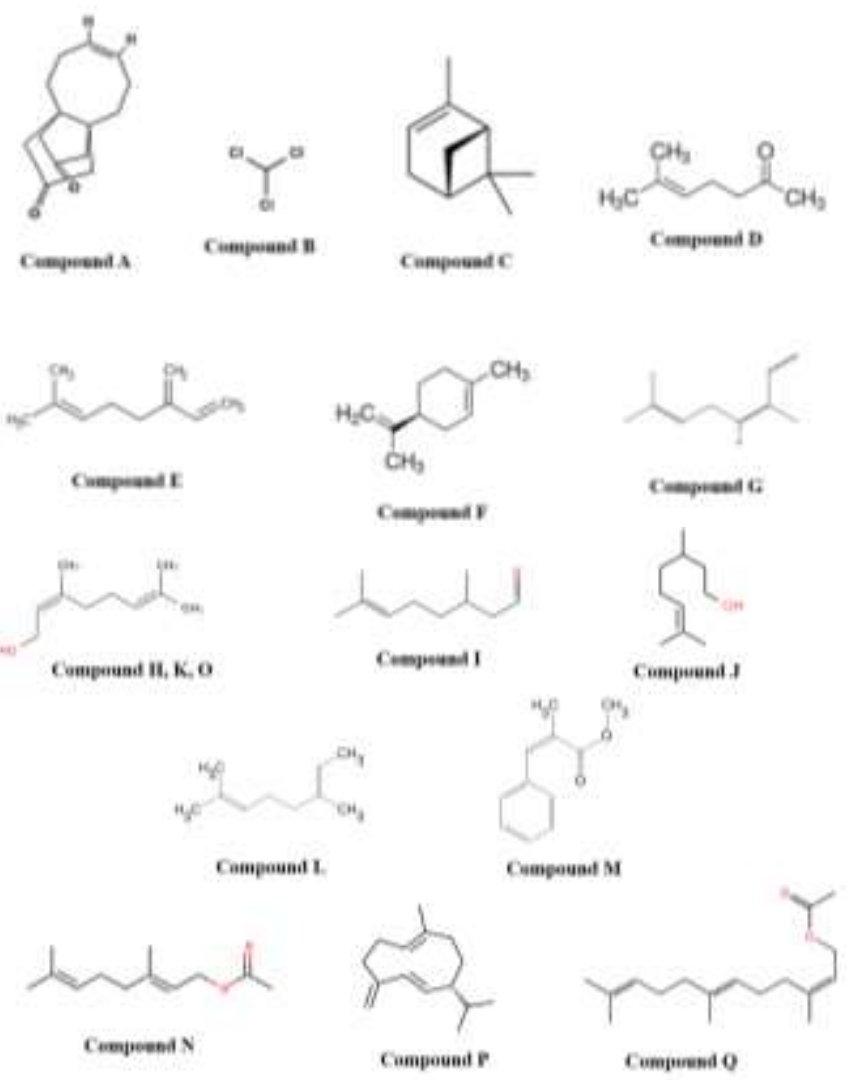

Figure 2. Secondary metabolites in the ruku-ruku leaves.

Based on the results of GCMS, there are at least 17 bioactive compounds in ruku-ruku leaves. The first compound that appeared at a retention time of 1,223 minutes was tricyclo $[6,3,3,0]$ tetradec-4-ene, 10,13-dioxo(compound A). Analysis of the existence of this compound was confirmed by comparing its fragmentation pattern to existing molecular banks. The similarity of the fragmentation pattern of compound A has $100 \%$ similarity to the fragmentation pattern that exists in the tricyclo $[6,3,3,0]$ tetradec-4-ene, 10,13-dioxo-. This compound has antibacterial activity. Compound A conducted an antibacterial test on the leaves of Eucalyptus maculata Hook. Inside the leaf contains compound A of 0.3 percent [4].

The same analysis was also carried out on the next peak compound, compound B. Based on the analysis of the similarity of fragmentary patterns, a $100 \%$ similarity to the fragmentation pattern of trichloromethane was obtained.

The same thing was done with the compounds $\mathrm{C}, \mathrm{D}$ and $\mathrm{E}$. Both of these compounds appeared around the 3,323, 4,063 , and 4,157 minutes. Based on the analysis of fragmentation patterns, it was found that the compounds $\mathrm{C}, \mathrm{D}$ and $\mathrm{E}$ were $1 \mathrm{~S}$ - $\alpha$-pinene, 6-methylhept-5-en-2one and myrcene with a percentage of chemistry similar to $100 \%$. These compounds $\mathrm{C}$ and $\mathrm{E}$ have antibacterial activity [5].

The sixth to ninth peaks are peaks that have the largest percentage of abundance in the sample. The abundance of compound F in Ruku-Ruku leaves was $59.04 \%$. Based on 
the analysis of the similarity of the fragmentation pattern of compound $\mathrm{F}$ has a $100 \%$ similarity to Limonene. This F compound has antibacterial activity against E. coli, S. aureus, B. substilis, and M. luteus [6]. At 5,410 minutes there was a peak showing the same fragmentation pattern with the compound 3,7-dimethyl-1,3,6-octatriene which is also called $\beta$-ocimene (compound G). $\beta$-ocimene has antibacterial activity against $\mathrm{S}$. pyogenes, $\mathrm{S}$. aureus and $\mathrm{E}$. aerogenes. Antibacterial activity is also present in compound $\mathrm{H}$ which appears at 6,581 minutes. The compounds that appear at that minute have the same structure in the compounds $\mathrm{K}$ and $\mathrm{O}$ that appear at 13.006 and 19.680 minutes. The three compounds have the same molecular formula, the structural formula of 3,7-dimethyl2,6-octadien-1-ol. The difference between the two compounds is the stereoisomer. Compound $\mathrm{H}$ is (2Z) -3,7dimethyl-2,6-octadient-1-ol, compound $\mathrm{K}$ is (2E) -3,7dimethyl-2,6-octadien-1-ol and compound $\mathrm{O}$ is cis geraniol. Nonetheless, this group of geraniol compounds has antibacterial activity against S. aureus, $\mathrm{L}$. monocytogenes, E. coli, and S. enterica [7]. At 8.692 minutes, the peak that appeared had a high percentage of abundance that was also compared to other peaks. Analysis of the compound I fragmentation pattern has similarities to the fragmentation pattern of citronellal compounds by $100 \%$, so that the compound I is concluded as a citronellal compound. This citronellal compound has antibacterial activity against $\mathrm{S}$. mutans, $\mathrm{L}$. casei, and cariogenic bacteria [8]. Compound I has a fairly large percentage of composition in leaves of Ruku-Ruku which is around $7.81 \%$. The same activity is also found in compound $\mathbf{J}$ which appears in 11.791 minutes which is a citronellol compound.

The L compound that appeared at 17,994 minutes was 2,6dimethyl-2,6-octadiene with a similarity percentage of $100 \%$ fragmentation pattern. The M compound which appeared at 19,280 minutes was methyl (2E) 3-phenyl-2propenoate with a similarity percentage of $100 \%$ fragmentation pattern. At 19,492 minutes, the analysis showed the presence of acetate geranyl on the leaves of Ruku-Ruku. Geranyl acetate has various biological activities such as antifungal of dermatophyte strains, C. neoformans and C. guillermondii [9]. This $\mathrm{N}$ compound is the second compound which has the highest number two percentage in the leaves of Ruku-Ruku that is equal to $14.80 \%$.

The next compound that was identified was found in the leaves of Ruku-Ruku namely germacene (compound P) which has the name IUPAC 8-isopropyl-1-methyl-5methylene-1,6-cyclodecadiene. The previous study conducted research on six species of Annonaceae from Monteverde, Costa Rica. Based on the results of GC MS, germacene contained quite a lot in these compounds. Antibacterial activity testing was carried out on B. cereus, S. aureus, and E. coli bacteria [10].

The last peak that appears on the GC results is the peak at 29,316 minutes. This peak identifies the compound Q which is farnesyl acetate which has the name 3,7,11trimethyl-1,6,10-dodecatrien-3-ol. This Q compound has biological activity as an antibacterial against $\mathrm{S}$. aureus, E. faecalis, E. faecium, E. coli, K. pneumoniae and A. baumannii [11].

\section{CONCLUSION}

This study has identified secondary metabolite compounds of ruku-ruku leaves from Batusangkar. The results showed that there were about 17 secondary metabolite compounds present in the ruku-ruku leaves. Limonnen, geranyl acetate, and citronellal are the major compounds in rukuruku leaves, with percentage respectively, $59.04 \%$, $14.80 \%$, and $7.81 \%$. In addition, secondary metabolites present in the ruku-ruku leaves have biological activities such as antibacterial properties.

\section{REFERENCES}

[1] A. K. A, Yuherman, and A. Zamri, "Isolasi Minyak Atsiri Daun Kemangi (Ocimum sanctum L.) Cara Konvensiolan dan Microwave serta uji aktivitas antibakteri dan antioksidan,” Repos. Univ. Riau, pp. 18,2016 .

[2] H. Parbuntari, S. B. Etika, M. Mulia, and E. Delvia, "A Preliminary Screening of the Different of Secondary Metabolites Ruku-Ruku Leaves ( Ocimum tenuiflorum Linnen ) in West Sumatera," vol. 20, no. 2, pp. 17-24, 2019.

[3] S. Zahra and Y. Iskandar, "Review Artikel: Kandungan Senyawa Kimia dan Bioaktivitas Ocimum Basilicium L.," Farmaka, vol. 15, no. 3, pp. 143-152, 2017.

[4] O. Zs, O. No, O. So, and A. So, "Composition and Bactericidal Activities of the Leaf Essential Oil of Eucalyptus maculata Hook," Nat. Prod. Chem. Res. Chem., vol. 5, no. 2, pp. 5-8, 2017.

[5] H. Zengin and A. H. Baysal, "Antibacterial and Antioxidant Activity of Essential Oil Terpenes against Pathogenic and Spoilage-Forming Bacteria and Cell Structure-Activity Relationships Evaluated by SEM Microscopy," molecules, vol. 19, pp. 1777317798, 2014.

[6] Z.-H. Li, M. Cai, Y.-S. Liu, P.-L. Sun, and S.L. Luo, "Antibacterial Activity and Mechanisms of Essential Oil from Citrus medica L. var. sarcodactylis," molecules, vol. 24, no. 1577, pp. 1-10, 2019.

[7] M. Zanetti et al., "Characterization of Pure Geraniol and Comparison with Bactericidal Activity of the Cinnamic Acid in Gram-Positive and Gram- 
Negative Bacteria,” J. Microb. Biochem. Technol. Microbiol., vol. 7, no. 4, pp. 186-193, 2015.

[8] R. S. Lemes et al., "Chemical composition and antibacterial activity of essential oils from Citrus aurantifolia leaves and fruit peel against oral pathogenic bacteria," An. Acad. Bras. Cienc., vol. 90, no. 2, pp. 1285-1292, 2018.

[9] M. J. Gonc et al., "Composition and biological activity of the essential oil from Thapsia minor, a new source of geranyl acetate," Ind. Crops Prod., vol. 35, pp. 166-171, 2012.

[10] M. C. Palazzo et al., "Chemical Compositions and Biological Activities of Leaf Essential Oils of Six Species of Annonaceae from Monteverde, Costa Rica," Rec. Nat. Prod., vol. 3, pp. 153-160, 2009.

[11] R. Bonikowski, P. Switakowska, M. Sienkiewicz, and M. Zaklos-Szyda, "Selected Compounds Structurally Related to Acyclic Sesquiterpenoids and Their Antibacterial and Cytotoxic Activity," molecules, vol. 20, pp. 11272-11296, 2015. 